\title{
Why is Yeast Such a Widely Used Eukaryotic Model Organism? A Literature Review
}

\author{
Dusan B. Pesic, BSc Student [1]
}

[1] Department of Anatomy and Cell Biology, McGill University, Montreal, Quebec, H3A 0G4

*Corresponding Author: dusan.pesic@mail.mcgill.ca

\begin{abstract}
Introduction: The use of yeasts in various fields dates back to thousands of years ago, but their biological significance has only recently been discovered. Genomes of many members of this relatively small group have been sequenced, and the consequent studies on them and on various cell processes have revealed similarities between yeast species Saccharomyces cerevisiae and Schizosaccharomyces pombe, and other eukaryotes, suggesting that they may be used as eukaryotic model organisms.

Methods: A literature search was conducted investigating general yeast characteristics, genetics and physiology, as well as modern applications in biomedical research as model organisms.

Results: Yeasts have many traits that make them especially favorable in research: they can easily be cultivated in laboratory conditions where their metabolism may be altered by tweaking the growth medium properties. Additionally, analyzing the yeast and human genome sequences has revealed astonishing similarities, with many successfully mapped homologous genes.

Discussion: By varying environmental conditions of a $S$. cerevisiae culture, it was found that such treatments could affect respiration in yeast. Proving useful in research of antifungal drugs and interactions between fungal pathogens and hosts, yeast was also used as a model for studying prion related diseases, Alzheimer's disease and cancer, amongst others.

Conclusion: With all the yeast characteristics - their simple requirements for growth, their genome and metabolism similar to other eukaryotes, and their use in studying varying disease conditions - it is understandable and clear why yeasts are such widely used model organisms. Considering recent advancements, their application in biomedical research will inevitably increase over time.
\end{abstract}

Keywords: yeast; S. cerevisiae; Schiz. pombe; model organism; gene homologs

\section{Introduction}

It often happens in biological and biomedical sciences that performing research on specific organisms, especially humans, is difficult due to ethical and practical reasons. In such cases, in vivo and in vitro procedures are performed using other organisms which exhibit similar patterns or phenomena. Such organisms are called model organisms and are dispersed all around the phylogenetic tree, including the fruit fly Drosophila melanogaster, nematode Caenorhabditis elegans, zebrafish Danio rerio, mouse Mus musculus, and, notably, yeast species, Saccharomyces cerevisiae and Schizosaccharomyces pombe [1].

Long before performing research or finding their application in biotechnology, humans have used yeast in food production, including in the fermentation of beers, ciders, wines, cheese, and other products [2]. While they are still used in such cases and in agriculture, novel biomedical applications of yeasts have created new opportunities for research. This is well illustrated by the fact that four Nobel Prizes were awarded between 2001 and
2013 for discoveries involving yeast research [3]. Historically, it was Louis Pasteur (1822-1895) who recognized that microorganisms were responsible for creating alcohol from sugar and observed the difference in alcoholic fermentation by yeasts and their aerobic growth. Saccharomyces cerevisiae was first isolated at the end of the $19^{\text {th }}$ century [4], while Emil Fischer and Eduard Büchner started investigating its metabolism about a century earlier.

There are 1,500 species of yeast and they are all unicellular organisms alternating between haploid and diploid phases, both of which can exist as stable laboratory cultures [5]. They vary in types of reproduction, making them suitable for exploring different phenomena. For instance, when studying cell division, fission yeast (Schizosaccharomyces pombe) is preferred to budding yeast (S. cerevisiae), given that "pombe" cells split into two cells similar to human cells, unlike budding yeast, which use buds for reproduction (Figure 1). 
UNDERGRADUATE RESEARCH IN NATURAL AND CLINICAL SCIENCE AND TECHNOLOGY (URNCST) JOURNAL Read more URNCST Journal articles and submit your own today at: $\underline{\text { https://www.urncst.com }}$

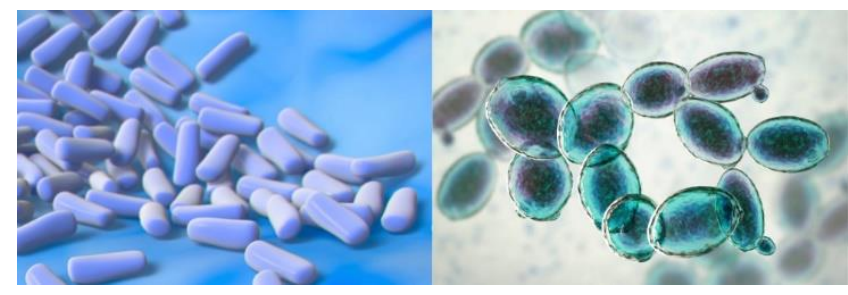

Figure 1. Schiz. pombe (left) and S. cerevisiae (right) cell shapes resulting from different means of division

The first ever eukaryotic genome to be sequenced is that of S. cerevisiae [6] and the other yeasts followed: Schiz. pombe, Schiz. japonicus, Schiz. cryophilus, and Schiz. octosporus [7]. Upon further analysis of their genomes, it was revealed that budding yeast's genome has undergone large duplications during evolution, resulting in the total of 16 total chromosomes, unlike the fission yeast whose karyotype has only three chromosomes [8].

When a model organism is being chosen for a human study, the choice is made depending on the process being researched. In aging, for example, cell cultures would not be preferred as cellular senescence mechanisms cannot be accurately extrapolated to human aging. Invertebrates $C$. elegans and D. melanogaster are chosen in this case. Ziehm et al. [9] proposed an uncommon approach for studying aging using these invertebrates - they used what is known about molecule-binding in higher organisms from the available data to transfer knowledge to the invertebrates which were then used to assess effects of compounds on organisms' viability. This enabled them to avoid testing the chemicals on higher organisms directly. The opposite approach is used in drug testing which is based on similarities between a simpler organism and humans. This allows the researchers to predict what would occur in humans with high certainty.

But of all the model organisms more closely related to humans than yeast, why would someone choose to use this unicellular fungus to study a human process? This paper aims to explore and compare why and how yeast can be used to model, and research human physiological conditions compared to other existing model organisms, and why it is so commonly used.

\section{Methods}

A literature search was conducted for articles describing basic yeast characteristics and historical uses, their physiology, genetics, more recent discoveries, and where different yeast species are used in research. Also, a search was conducted for literature describing other model organisms. The search engine used was Google Scholar, and the key words used include "yeast," "Saccharomyces," "Schizosaccharomyces," "model organism," "gene homology," and "cultivation conditions." The years of publication for the literature used ranged from 1991 to 2021.

\section{Results}

General characteristics of yeast

Key characteristics of some of the most commonly used model organisms are outlined in Table 1.

Table 1. Commonly used model organisms

\begin{tabular}{|l|l|l|l|}
\hline \multicolumn{1}{|c|}{ Model organism } & \multicolumn{1}{|c|}{ Characteristics } & \multicolumn{1}{c|}{ Cultivation conditions } & \multicolumn{1}{c|}{ Advantages } \\
\hline Escherichia coli & $\begin{array}{l}\text { Gram-negative bacterium, } \\
\text { facultatively anaerobic } \\
{[10], \text { human pathogen. }}\end{array}$ & $\begin{array}{l}\text { In growth media, the optimal } \\
\text { temperature is between } 35 \\
\text { and } 40^{\circ} \mathrm{C}, \mathrm{pH} \text { ranges from } \\
4.4 \text { to } 10 .\end{array}$ & $\begin{array}{l}\text { The most extensively studied } \\
\text { microorganism, not difficult to } \\
\text { cultivate, sequenced genome, fast } \\
\text { reproduction cycle. }\end{array}$ \\
\hline Saccharomyces cerevisiae & $\begin{array}{l}\text { Unicellular fungus, } \\
\text { "baker's" yeast, divides by } \\
\text { budding, used in food } \\
\text { industry [11]. }\end{array}$ & $\begin{array}{l}\text { In growth media, the optimal } \\
\text { temperature is between } 25 \text { and } \\
35^{\circ} \mathrm{C}, \text { and the pH is between } \\
4.5 \text { and } 6.5 .\end{array}$ & $\begin{array}{l}\text { Eukaryotic, easily cultivated and } \\
\text { genetically manipulated, cultures } \\
\text { can be either haploid or diploid, } \\
\text { sequenced genome (Saccharomyces } \\
\text { Genome Database), fast } \\
\text { reproduction cycle. }\end{array}$ \\
\hline Caenorhabditis elegans & Nematode, 1 mm long [12]. & $\begin{array}{l}\text { In a medium, often with } \\
\text { bacteria as a food source [13]. }\end{array}$ & $\begin{array}{l}\text { Eukaryotic, relatively simple } \\
\text { cultivation, fast reproduction cycle. }\end{array}$ \\
\hline Drosophila melanogaster & The "fruit fly," insect. & $\begin{array}{l}\text { Cultures are kept in } \\
\text { "population cages" [14] and } \\
\text { the process is more complex } \\
\text { than having cell culture. }\end{array}$ & $\begin{array}{l}\text { Fast reproduction cycle, } \\
\text { commonly used in genetics (used } \\
\text { to prove the chromosomal theory } \\
\text { of inheritance [15]). }\end{array}$ \\
\hline Mus musculus & $\begin{array}{l}\text { Many factors need to be } \\
\text { considered: temperature and } \\
\text { humidity, ventilation and air } \\
\text { quality, illumination, acoustics, } \\
\text { amongst others. }\end{array}$ & $\begin{array}{l}\text { 99\% gene homology with humans } \\
{[16], \text { a mammal- more closely }} \\
\text { related to humans and even } \\
\text { exhibits some of the same } \\
\text { conditions. }\end{array}$ \\
\hline
\end{tabular}


UNDERGRADUATE RESEARCH IN NATURAL AND CLINICAL SCIENCE AND TECHNOLOGY (URNCST) JOURNAL Read more URNCST Journal articles and submit your own today at: https://www.urncst.com

External environment and yeast growth conditions can be modified in different ways through varying chemical and environmental factors [7]. In the study on effects of different cultivation conditions on $S$. cerevisiae mitochondria, Visser et al. [17] found that varying glucose and ethanol concentrations in the medium influenced the repression of respiratory enzymes, leading to morphological changes in their mitochondria. This study reinforces the use of chemostat cultivation as a way of studying the regulation of respiratory activity in yeasts. The method is based on keeping the volume of the medium constant by continuously adding and removing the fluid containing biomass, products, and nondepleted nutrients [18].

\section{$\underline{\text { Yeast in genetic research }}$}

Another important yeast characteristic is that its genome is well suited for genetic analysis, with different techniques shown to be successful in accurately replacing wild type genes with mutant alleles [19]. Despite having significant differences in cell and tissue organization, motility, metabolism, and external environment, with the most recent common ancestor from around one billion years ago [20], humans and yeasts have more than a thousand homologous genes [21]. The genome of Schiz. pombe contains protein-encoding genes approximately every $2.3 \mathrm{~kb}$ [22], compared to another commonly used model organism, C. elegans, where such can be found on average every $6 \mathrm{~kb}$ [23]. Even with a small genome compared to that found in humans, $12 \mathrm{Mb}$ compared to 3,200 [24], the key processes in yeasts including autophagy, protein translocation and secretion, heat shock, protein folding, chaperone functions, and endoplasmic reticulumassociated protein degradation are highly conserved [25]. Further genetic analyses have contributed to our knowledge of yeast-human gene homology. Soon after sequencing the Saccharomyces genome, by creating deletions in most of the open reading frames, a deletion library was created [26]. This set the ground for the discovery of biological roles of most of the yeast genes, which is known for more than $85 \%$ of them, higher than for any other eukaryote. Only $34 \%$ of the entire set of genes with mammalian homologs have no function listed in the Saccharomyces Genome Database (SGD), compared to less than $25 \%$ of the genes having the strongest homology [26]. While the reason for this is largely unknown, there is a possibility that scientists studying yeast have concentrated on the most important genes which are more likely to be conserved. At least 71 human genes complement yeast mutations, but this is certainly an underestimate [26]. Due to these features, yeasts have been used as model organisms for studying various diseases and conditions, examples of which can be found in Table 2.
Table 2. Diseases studied by using $S$. cerevisiae as a model organism; adapted from [2]

\begin{tabular}{|c|c|}
\hline Disease & Reference \\
\hline Prion related diseases & 27 \\
\hline Alzheimer's disease & 28 \\
\hline Parkinson's disease & 29 \\
\hline Cancer & 30 \\
\hline Aging & 31 \\
\hline
\end{tabular}

\section{Discussion}

While there are other organisms that also have genetic homologies with humans similar to the baker's yeast, there are impediments in using them for research purposes. If two potential model organisms exhibit the same trait, the simpler one will be chosen. For example, $99 \%$ of $M$. musculus genes have their homologs in humans, higher than any other organisms [16]. But given that it is a mammal, it must be housed and handled following specific conditions, which are more complex compared to those used to develop a microbial culture. Also, there are ethical and legislative barriers to using "higher organisms," making individuals and institutions seek alternatives for their research. Bacteria, much simpler organisms, come as a good alternative. The Ames test is an excellent reminder of how they are be used to assess mutagenicity, instead of a cell line [32]. However, they do not come without drawbacks of their own-namely, there are species of bacteria are referred to as viable, but nonculturable, meaning that their metabolism functions slowly and they do not divide. Performing research on them is extremely difficult. Additionally, prokaryotes are much simpler than eukaryotes including humans and yeasts, and this drastically limits what can concluded about more complex eukaryotes from findings in such experiments. For example, given that bacterial DNA is not organized in chromosomes, gene regulation is simpler than in eukaryotes where chromatin has an important role among other factors. This is where $S$. cerevisiae and Schiz. pombe come as exceptional model organisms. As mentioned earlier and similar to many bacteria, they are easy to cultivate and their growth media can be adjusted to modify their metabolism. While E. coli is simpler to cultivate, the yeast cell culture is still easier to maintain compared to other commonly used eukaryotic model organisms.

Given the observed gene homology, S. cerevisiae and Schiz. pombe have been utilized as models to explain various phenomena in humans. Despite having a smaller genome, Schiz. pombe has proportionally more genes preserved in animals [6], although S. cerevisiae is preferred when studying some cellular functions-namely, it was key in exploring physiology of the peroxisome [33]. 
UNDERGRADUATE RESEARCH IN NATURAL AND CLINICAL SCIENCE AND TECHNOLOGY (URNCST) JOURNAL Read more URNCST Journal articles and submit your own today at: https://www.urncst.com

Nonetheless, using a compare and contrast approach, both yeasts have been used to characterize genes involved in regulating normal events in cell cycle progression [6]. Utilizing yeast as a model has led to other discoveries. Given that it lacks endogenous nuclear receptor and receptor regulatory proteins found in mammalian cell lines [2], a great use has been made of it for studying activation of human receptors by anti-estrogens [34]. S. cerevisiae has also been used for developing diagnostics and to better understand mechanisms of various antifungal drugs [35] and interactions between fungal pathogens and hosts [36] As mentioned earlier, a yeast culture can be either haploid or diploid and each type can be applied for different studies. Haploid cultures can be useful in screening as mutant phenotypes are expressed in such cases. On the other hand, diploid cultures are a good tool in performing complementation tests, exploring gene interactions, or "silencing" deleterious mutations. Considering the homology observed between yeast and other eukaryotes, findings of such experiments can suggest what occurs in higher organisms.

Considering cultivation conditions and the extent to which the genome is studied - it is of no surprise that yeast is such a widely used model organism. Its characteristics and genetic similarities with other organisms make it suitable and easily adaptable for researching metabolism, gene expression, and other common eukaryotic processes, as well as for processes unique to higher groups but with the same genetic basis.

\section{Conclusions}

Morphological, physiological, and genetic characteristics of yeasts, namely $S$. cerevisiae and Schiz. pombe, give researchers a variety of biological tools they can use: the cultivation environment can be tweaked to modify the yeast metabolism in a certain way, and by knowing its genome sequence and having different databases, it is possible to use the yeast for different genetic research and understand its metabolism on a molecular level. Genetic analysis also revealed that many of its genes have been preserved in evolutionary younger organisms, resulting in many cellular processes being similar or same, and making yeast a great model organism for other eukaryotes. This has allowed for them to be used for studying prion related diseases, Parkinson's disease, and aging, amongst others.

\section{List of Abbreviations Used}

S. cerevisiae: Saccharomyces cerevisiae

Schiz. pombe: Schizosaccharomyces pombe

Schiz. japonicus: Schizosaccharomyces japonicus

Schiz. cryophilus: Schizosaccharomyces cryophilus

Schiz. octosporus: Schizosaccharomyces octosporus

C. elegans: Caenorhabditis elegans

D. melanogaster: Drosophila melanogaster

SGD: Saccharomyces Genome Database

M. musculus: Mus musculus

E. coli: Escherichia coli

\section{Conflicts of Interest}

The author declares that he has no conflict of interests.

\section{Ethics Approval and/or Participant Consent}

The study required no ethics approval or participant consent.

\section{Authors' Contributions}

DP: contributed to the design of the study, the review of literature and collection of data, interpretation and analysis of the data, and revised the manuscript.

\section{Acknowledgements}

I wish to thank my mentor, Mythili Ravishankar, for her support, help in literature search, and for reviewing the manuscript. I would also like to thank Bi-ru Amy Yeung for carefully reviewing my manuscript several times and helping me with its revision.

\section{Funding}

This study was not funded.

\section{References}

[1] Leonelli S, Ankeny RA. What makes a model organism? Endeavour [Internet]. 2013;37(4):209-12. http://doi.org/10.1016/j.endeavour.2013.06.001

[2] Johnson EA, Echavarri-Erasun C. Yeast biotechnology [Internet]. Vol. 1, The yeasts. Elsevier B.V. 2011;21-44. http://doi.org/10.1016/B978-0-444-52149-1.00003-3

[3] Using yeast in biology [Internet]. Yourgenome. [cited 2021 Apr 2]. Available from: https://www.yourgenome .org/stories/using-yeast-in-biology\#: :text=Yeast $\%$ 20is\%20a\%20powerful\%20model,in\%201996\%20and $\% 20$ the $\% 20 \mathrm{~S}$.

[4] Dequin S. The potential of genetic engineering for improving brewing, wine-making and baking yeasts. Applied Microbiology and Biotechnology. 2001;56(56):577-88. https://doi.org/10.1007/s002530100700 
UNDERGRADUATE RESEARCH IN NATURAL AND CLINICAL SCIENCE AND TECHNOLOGY (URNCST) JOURNAL Read more URNCST Journal articles and submit your own today at: https://www.urncst.com

[5] Topley WWC, Wilson GS, Collier LH, Mahy BWJ, Ter Meulen V, Topley WWC, et al. Topley \& Wilson's microbiology and microbial infections. [Internet]. London; New York: Hodder Arnold ; ASM Press; 2005 [cited 2021 Aug 15]. Available from: http://mrw.interscience.wiley.com/emrw/97804706886 18/home/

[6] Goffeau A, Barrell BG, Bussey H, Davis RW, Dujon B, Feldmann H, et al. Life with 6000 genes. Science. 1996;274(5287):546-67. https://doi.org/10.1126/science.274.5287.546

[7] Aoki K, Furuya K, Niki H. Schizosaccharomyces japonicus: A distinct dimorphic yeast among the fission yeasts. Cold Spring Harbour Protocols. 2017;2017(12):963-73. https://doi.org/10.1101/pdb.top082651

[8] Forsburg SL. The art and design of genetic screens: Yeast. Nature Reviews Genetics. 2001;2(9):659-68. https://doi.org/10.1038/35088500

[9] Ziehm M, Kaur S, Ivanov DK, Ballester PJ, Marcus D, Partridge L, et al. Drug repurposing for aging research using model organisms. Aging Cell. 2017;16(5):100615. https://doi.org/10.1111/acel.12626

[10] Desmarchelier P, Fegan N. Escherichia Coli. In: Roginski H, editor. Encyclopedia of Dairy Sciences [Internet]. Oxford: Elsevier; 2002. 948-54.

[11] Stewart GG. Saccharomyces | Saccharomyces cerevisiae. In: Batt CA, Tortorello ML, editors. Encyclopedia of Food Microbiology (Second Edition) [Internet]. Second Edition. Oxford: Academic Press; 2014. 309-15.

[12]El-Bawab F. Chapter 9 - Phylum Nematoda. In: El-Bawab F, editor. Invertebrate Embryology and Reproduction [Internet]. Academic Press; 2020; 422-70. https://doi.org/10.1016/B978-0-12-8141144.00009-6

[13] Flavel MR, Mechler A, Shahmiri M, Mathews ER, Franks AE, Chen W, et al. Growth of Caenorhabditis elegans in defined media is dependent on presence of particulate matter. G3 (Bethesda). 2017 Dec 8;8(2):567-75. https://doi.org/10.1016/B978-0-12814114-4.00009-6

[14] Caravaca JM, Lei EP. Maintenance of a Drosophila melanogaster population cage. Journal of Visualized Experiments. 2016 Mar 15;(109):53756. https://doi.org/10.3791\%2F53756

[15] Tolwinski NS. Introduction: Drosophila-A model system for developmental biology. Journal of Developmental Biology. 2017 Sep 20;5(3):9. https://doi.org/10.3390\%2Fjdb5030009

[16] Han S, Yang A, Lee S, Lee H-W, Park CB, Park H-S. Expanding the genetic code of Mus musculus. Nature Communication. 2017 Feb 21;8(1):14568. https://doi.org/10.1038/ncomms 14568
[17] Visser W, van Spronsen EA, Nanninga N, Pronk JT, Kuenen JG, van Dijken JP. Effects of growth conditions on mitochondrial morphology in Saccharomyces cerevisiae. Antonie Van Leeuwenhoek. 1995;67(3):24353. https://doi.org/10.1007/BF00873688

[18] Van Dijken JP, Weusthuis RA, Pronk JT. Kinetics of growth and sugar consumption in yeasts. Antonie Van Leeuwenhoek. 1993;63(3-4):343-52. https://doi.org/ $\underline{10.1007 / B F 00871229}$

[19] Wach A, Brachat A, Pöhlmann R, Philippsen P. New heterologous modules for classical or PCR-based gene disruptions in Saccharomyces cerevisiae. Yeast. 1994 Dec;10(13):1793-808. https://doi.org/10.1002/yea .320101310

[20] Kumar S, Stecher G, Suleski M, Hedges SB. TimeTree: A resource for timelines, timetrees, and divergence times. Molecular Biology and Evolution. 2017;34(7):1812-9. https://doi.org/10.1093/molbev/ $\underline{\operatorname{msx} 116}$

[21] Remm M, Storm CEV, Sonnhammer ELL. Automatic clustering of orthologs and in-paralogs from pairwise species comparisons. Journal of Molecular Biology. 2001 Dec 14;314(5):1041-52. https://doi.org/10.1006/ jmbi.2000.5197

[22]Wood V, Gwilliam R, Rajandream MA, Lyne M, Lyne $\mathrm{R}$, Stewart A, et al. The genome sequence of Schizosaccharomyces pombe. Nature. 2002;415(6874): 871-80. https://doi.org/10.1038/nature724

[23] Blumenthal T, Spieth J. Gene structure and organization in Caenorhabditis elegans. Current Opinion in Genetics and Development. 1996;6(6):6928. https://doi.org/10.1016/S0959-437X(96)80022-0

[24] Engel SR, Dietrich FS, Fisk DG, Binkley G, Balakrishnan R, Costanzo MC, et al. The reference genome sequence of Saccharomyces cerevisiae: Then and now. G3 Genes|Genomes|Genetics. 2014;4(3):38998. https://doi.org/10.1534\%2Fg3.113.008995

[25] Nielsen J. Yeast systems biology: Model organism and cell factory. Biotechnology Journal [Internet]. 2019;14(9):1-9. http://doi.org/10.1002/biot.201800421

[26] Botstein D, Fink GR. Yeast: An experimental organism for 21 st century biology. Genetics. 2011;189(3):695704. https://doi.org/10.1534/genetics.111.130765

[27] Nakayashiki T, Kurtzman CP, Edskes HK, Wickner RB. Yeast prions [URE3] and [PSI+] are diseases. Proceedings of the National Academy of Sciences. 2005;102(30):10575-80. https://doi.org/10.1073/pnas .0504882102

[28] Vishnevskaya AB, Kushnirov V V., Ter-Avanesyan MD. Neurodegenerative amyloidoses: Yeast model. Molecular Medicine. 2007;41(2):308-15. https://doi.org/10.1134/S0026893307020112 
UNDERGRADUATE RESEARCH IN NATURAL AND CLINICAL SCIENCE AND TECHNOLOGY (URNCST) JOURNAL

Read more URNCST Journal articles and submit your own today at: https://www.urncst.com

[29] Doostzadeh J, Davis RW, Giaever GN, Nislow C, Langston JW. Chemical genomic profiling for identifying intracellular targets of toxicants producing Parkinson's disease. Toxicological Sciences. 2007 Jan;95(1):182-7. https://doi.org/10.1093/toxsci/kfl131

[30] Hartwell LH. Yeast and cancer. Bioscience Reports. 2002;22(3-4):373-94. https://doi.org/10.1023/ a:1020918107706

[31] Piper PW. Long-lived yeast as a model for ageing research. Yeast. 2006;23(3):215-26. https://doi.org/ 10.1002/yea. 1354

[32] Föllmann W, Degen G, Oesch F, Hengstler JG. Ames Test. In: Maloy S, Hughes K, editors. Brenner's encyclopedia of genetics (Second Edition) [Internet]. San Diego: Academic Press; 2013 [cited 2021 Jul 10]. 104-7.
[33] Evers ME, Höhfeld J, Kunau WH, Harder W, Veenhuis M. Physiological studies on the utilization of oleic acid by Saccharomyces cerevisiae in relation to microbody development. FEMS Microbiology Letters. 1991;90(1):73-8. https://doi.org/10.1111/j.1574-6968 1991.tb05128.x

[34] Dudley MW, Sheeler CQ, Wang H, Khan S. Activation of the human estrogen receptor by the antiestrogens ICI 182,780 and tamoxifen in yeast genetic systems: Implications for their mechanism of action. Proceedings of the National Academy of Sciences. 2000;97(7):3696-701. https://doi.org/10 $.1073 /$ pnas.97.7.3696

[35] Weig M, Brown AJP. Genomics and the development of new diagnostics and anti-Candida drugs. Trends in Microbiology. 2007;15(7):310-7. https://doi.org/ 10.1016/j.tim.2007.05.007

[36] Panepinto JC, Heinz E, Traven A. The cellular roles of Ccr4-NOT in model and pathogenic fungi-implications for fungal virulence. Frontiers in Genetics. 2013;4:112. https://doi.org/10.3389\%2Ffgene.2013.00302

\section{Article Information}

Managing Editor: Jeremy Y. Ng

Peer Reviewers: Mythili Ravishankar, Bi-ru Amy Yeung

Article Dates: Received Apr 03 21; Accepted Jul 27 21; Published Sep 0321

\section{Citation}

Please cite this article as follows:

Pesic DB. Why is yeast such a widely used eukaryotic model organism? A literature review. URNCST Journal. 2021 Sep 03: 5(9). https://urncst.com/index.php/urncst/article/view/259

DOI Link: https://doi.org/10.26685/urncst.259

\section{Copyright}

(C) Dusan B. Pesic. (2021). Published first in the Undergraduate Research in Natural and Clinical Science and Technology (URNCST) Journal. This is an open access article distributed under the terms of the Creative Commons Attribution License (https://creativecommons.org/licenses/by/4.0/), which permits unrestricted use, distribution, and reproduction in any medium, provided the original work, first published in the Undergraduate Research in Natural and Clinical Science and Technology (URNCST) Journal, is properly cited. The complete bibliographic information, a link to the original publication on http://www.urncst.com, as well as this copyright and license information must be included.
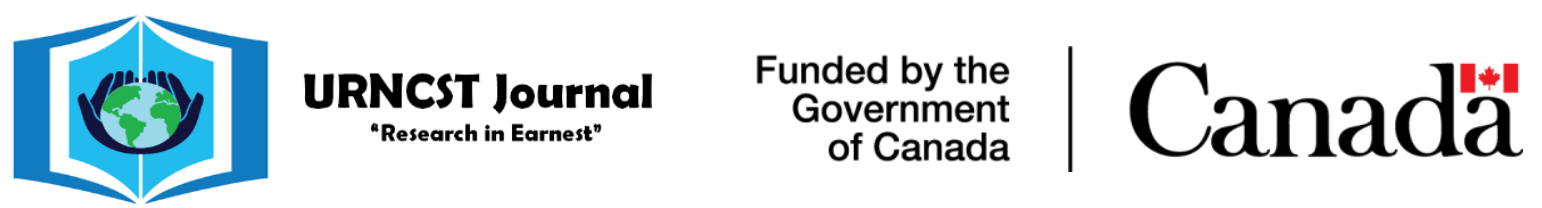

Do you research in earnest? Submit your next undergraduate research article to the URNCST Journal!

| Open Access | Peer-Reviewed | Rapid Turnaround Time | International |

| Broad and Multidisciplinary | Indexed | Innovative | Social Media Promoted |

Pre-submission inquiries? Send us an email at info@ urncst.com | Facebook, Twitter and LinkedIn: @URNCST

Submit YOUR manuscript today at https://www.urncst.com! 